whole massif, although it is implied to be tabular. When the authors come to the pegmatites, and the rare-element geochemistry, they are much more at home, and to this extent the book is mis-titled. Much of the description and the discussion throughout is ponderous and repetitive, although the reader searching for comparative data will find some good summaries and some excellent tables. The plates are of very mixed quality, and a number of figures have unsatisfactory explanations, seales or ornaments. The section on mineralogy is long and of variable consistency-petrologists will be disappointed by the section on rock-forming minerals; the pigeon-holing of some of the others, for example titanosilicates, tends to obscure their affinities. The final section of the book, on geochemistry and genesis, usefully gathers together many loose ends, but some of the averaging of chemical data is open to the criticism that the analyses, and the proportions of each, are not cited. The subsequent account of the mode of formation is not "a stimulating starting point for discussion". Nowhere is the suggested four-stage formation of rocks, as well as pegmatites, clearly substantiated. The remarkable mineral layering at Lovozero is ascribed to crystallization differentiation, but the mechanics of segregation are not postulated, and the phase-conditions governing the suggested sequences of erystallization are not considered. A serious defect in this discussion is the scant consideration given to the neighbouring Khibiny massif; only the average chemistry is compared with that of Lovozero, and also, strangely, with Vishnevogorsk (only the reader familiar with Soviet geology would appreciate the latter incongruity-Vishnevogorsk is in the Urals province). In short, the factual part of this book is an invaluable, if unwieldy, addition to our knowledge of this uniquely important igneous complex.

D. K. BAILEY

\section{FEEDING FRUIT CROPS}

\section{Nutrition of Fruit Crops}

Tropical, Sub-tropical, Temperate. Edited by Norman Franklin Childers. Pp. $x v+888$. (New Brunswick, N.J.: Horticultural Publications, Rutgers University, 1966.) n.p.

Most of the perennial plants that bear fruit crops of economic importance have much in common in their morphology and physiology, and certain general principles underlie their nutrition. Much empirical work has been carried out to determine responses to fertilizers and attempts have been made to provide bases for generalization about the application of results with a given crop to the various conditions in which the crop is grown. Little has been done, however, to integrate the research results to develop a generalized account of the nutrition of fruit plants. Although the present publication does not set out to do this, it performs a useful service in bringing together in one large book reviews on the nutrition of individual fruit crops.

Of the twenty-four chapters, nineteen are reviews, with lists of references, on the nutrition of apple; avocado and mango; banana; blueberry and cranberry; bush fruits; cacao; cherry; citrus; coconut; coffee; grape; olive; edible nuts; peach; pear; pineapple; plum, prune and apricot; strawberry; and tung. These reviews are mostly by American experts concerned with the respective crops. They show great variation in length and treatment; some give a critical assessment of their subject, while others provide a catalogue of experimental results sometimes in extensive tables quite out of place in this book. Many of the chapters retain the same form as in the original edition of 1954, the authors having been content merely to insert additional paragraphs, but some have been re-written. The accounts of the nutrition of banana, eacao, coconut, coffee, olive and pineapple are all new.
The book also includes chapters dealing with the use of leaf analysis as a guide to the nutrition of deciduous fruits and citrus respectively, an account of the use of chelated metals for supplying micronutrients to fruit crops, a chapter on experimentation with orchard trees, a comprehensive table of nutrient concentrations in fruit plant tissues in relation to the appearance of symptoms, and a ninety-eight page insert of monochrome photographs illustrating deficiency symptoms.

The contributions are all virtually independent. With fow exceptions, there are not even any cross-references between the texts and the photographic section, so one has to use the subject index, fortunately a good one.

Defects occur, but they do not detract seriously from the value of this collection as a source of reference, on the whole well produced. Those concerned with the nutrition of one type of fruit crop should find it useful to consider what may be learned from the approach of others working with similar crops. $\quad$ D. W. P. GReEnHaM

\section{ECOLOGY LOOKS AHEAD}

\section{Systems Analysis in Ecology}

Edited by Kenneth E. F. Watt. Pp. xiii + 276. (New York : Academic Press, Inc.; London: Academic Press Inc. (London), Ltd., 1966.) \$1.1.50.

THIs is an excellent compendium of several recent and sophisticated research projects which have utilized electronic sampling devices followed by computer simulation or analysis.

Despite careful selection of the material, however, the reader is left with the impression that this, "the first book to present a detailed exposition of new electronic and computer procedures", is a little premature in its appearance. In several instances it is clear the authors themselves have indulged in some wishful thinking. The realism, for example, of both the direct study of bird navigation by means of orbital satellites, and direct links of computer with experimental situation, are both cases in point.

Many ecologists are not only aware of the complexity of the ecosystem and the desirability of team research but are also aware of the large gaps in our existing knowledge. This in turn leads to highly simplified simulation models. The wide range of the contents of this book does suggest a variety of ways in which the necessary data can be collected and handled by computer and it is in this respect a useful contribution.

It gives a firm jolt to those ecologists who are still prepared to amble along with merely notebook and pencil. Equally it promises those of us with an inadequate mathematical and electronic background some heavy going in the future.

K. A. Kershaw

\section{NORTH AFRICAN BIRDS}

\section{The Birds of North Africa}

From the Canary Islands to the Red Sea. By R. D. Etchécopar and François Hüe. Translated by P. A. D. Hollom. Pp. $\mathrm{xx}+612+24$ plates. (Edinburgh and London: Oliver and Boyd, Ltd., 1967.) 168s. net.

As I remarked in the notice of the original edition of this book (Nature, 205,$9 ; 1965)$ it was appropriate that this valuable work of reference should be a product of French ornithology, which has been so notably active in the area. The material in the book is, however, also of great interest to British ornithologists and this English edition is welcome. The translator is one of the authors of the well known Field Guide to the Birds of Britain and Europe and himself a frequent visitor to North Africa. The present 